\title{
Em busca de um padrão: moda, beleza e vida social na obra de Joaquim Manuel de Macedo*
}

\author{
In search of a pattern: fashion, beauty and social life in the work of Joaquim Manuel de \\ Macedo
}

\section{Mariana de Paula Cintra}

Doutoranda em História e Cultura Social/ Unesp Franca marianacintradepaula@gmail.com

Resumo: É consenso na historiografia que o século XIX inaugurou algumas transformações estruturais no Rio de Janeiro, cidade sede da corte. A abertura dos portos brasileiros às nações amigas, em 1808, possibilitou, dentre outros avanços, a circulação da palavra impressa naquela sociedade. A criação de uma imprensa nacional desempenhou um papel importante para a propagação de novas ideias, notícias e costumes vindos do estrangeiro. Inseridas nessa conjuntura, as damas abastadas começaram a se moldar segundo os padrões vindos, particularmente, da Europa. Tendo como documentação os primeiros romances nacionais publicados na capital brasileira da época, o presente artigo busca mapear as roupas e os ambientes sociais cariocas por meio das mocinhas de Macedo, analisando de que modo esses enredos forjaram um tipo de mulher ideal para a época.

Palavras-chave: Moda, Romances, Mulheres.

\begin{abstract}
It is a consensus in historiography that the nineteenth century inaugurated some structural transformations in Rio de Janeiro, the seat of the court. The opening of Brazilian ports to friendly nations, in 1808, made possible, among other advances, the circulation of the printed word in that society. The creation of a national press played an important role in spreading new ideas, news and customs from abroad. Inspired by this juncture, the wealthy ladies began to shape themselves according to the standards, particularly of Europe. Based on the documentation of the first Brazilian novels published in the Brazilian capital of the time, the present article seeks to map Carioca clothing and social environments through Macedo's young girls, analyzing how these entanglements forged an ideal type of woman for the time.
\end{abstract}

Keywords: Fashion, Affairs, Women. 


\section{O Rio de Janeiro dos romances}

A embriaguez se tornou mais notável. As ideias deste século pervertido são contagiosas; povos inteiros padeceram o mesmo mal; o brasileiro não podia formar exceção [...] os velhos se tornaram crianças, os meninos não tomaram mais a benção a seus pais, as moças desprezaram os véus da modéstia e a vida sossegada da solidão, para irem com o rosto bem à mostra, e carregadas de adornos e de modas indecentes, dançar em saraus, onde a licença e o desregramento tomaram o nome de civilização e de progresso (MACEDO, 1980: 96).

As palavras acima, retiradas do romance oitocentista $O$ moço loiro, ilustram um tipo de discurso que não aceitava o advento do progresso e da modernidade no Rio de Janeiro do século XIX. Tal excerto, numa leitura apressada, não parece significar mais que o desabafo de um personagem cujos ideais ainda propagavam uma mentalidade própria da colônia, mas, se compreendido em seu contexto, possibilita a compreensão das mudanças ocorridas na sociedade e na sociabilidade carioca do Oitocentos, à medida que expõe os novos comportamentos, pensamentos e, especialmente, alguns padrões de moda do chamado belo sexo. É nessa última perspectiva, portanto, que pretendemos estudar os primeiros escritos do gênero romance na cidade do Rio de Janeiro, então capital do Império brasileiro. Joaquim Manuel de Macedo, escritor de obras substanciais que muito diziam sobre o cotidiano da cidade fluminense e autor das primeiras experiências do romance, na qualidade de gênero literário, nos instiga a explorar, mais profundamente, o papel dessas narrativas ficcionais para a escrita da História e, notadamente, para a reconstrução dos modos de vestir, de se embelezar e de socializar da alta sociedade carioca à época. ${ }^{1}$

\footnotetext{
${ }^{1} \mathrm{O}$ presente artigo é um recorte da pesquisa que desenvolvi no mestrado, na qual busquei mapear as descrições sobre a indumentária feminina no Rio de Janeiro, nos quatro primeiros romances de Joaquim Manuel de Macedo, publicado na capital brasileira da época, bem como as prescrições para o bem vestir das mulheres nos jornais de modas também ali publicados. O propósito fundamental da pesquisa foi analisar os tipos vestimentários do belo sexo da boa sociedade carioca, levando em consideração que a vinda da corte portuguesa em 1808, acarretou inúmeras mudanças nos estilos de vida e na sociabilidade dos homens - mas, especialmente, das mulheres cariocas - no decorrer do século dezenove. Em última instância, o intuito foi pensar o contexto oitocentista no Rio de Janeiro como terreno fértil para o despertar de uma preocupação mais evidente com os modos de vestir das mocinhas da época. Essa forma de abordagem, portanto, compartilha dos mesmos pressupostos do projeto temático "Escritos sobre os novos mundos: uma história da construção de valores morais em língua portuguesa", do qual essa pesquisa faz parte. Disponível em: <//www.bv.fapesp.br/pt/auxilios/90522/escritos-sobre-os-novos-mundos-uma-historia-da construcaode- valores-morais-em-lingua-portuguesa/>.
} 
Partindo da informação que os romances foram discursos presentes na vida diária das mocinhas do Rio de Janeiro e que souberam retrarar os tipos de indumentária recomendados à vida pública de outrora - ao lado dos jornais e guias de boas maneiras - este artigo procura mapear a importância desses escritos ficcionais para compreender a dinâmica de moda, de beleza e de sociabilidade das mulheres. Tangenciados alguns dos propósitos primordiais desse estudo faremos, em primeiro plano, uma análise geral da cidade fluminense no Oitocentos e algumas considerações sobre os romances aqui elencados, afim de situarmos o leitor no espaço e no tempo aos quais dizem respeito este trabalho. Em seguida, apresentaremos os lugares da vida mundana mais frequentados pelas moças e como tais espaços foram tangenciados por Macedo, e, por fim, mapearemos quais eram os tipos de roupas e padrões de beleza que essas mulheres costumavam apresentar nesses ambientes. Em outros termos, os questionamentos que nortearão essa escrita podem ser assim resumidos: qual era a moda vigente no Rio de Janeiro entre as mocinhas oitocentistas segundo as descrições dos primeiros romances brasileiros? O que essas vestimentas e esses discursos podem nos revelar sobre as mulheres e os lugares atribuídos a elas na sociedade da época?

Sabemos que o início do século XIX marcou um momento de importantes mudanças nos rumos do Brasil enquanto colônia portuguesa, sobretudo, porque em 1808, Dom João e sua família, juntamente com a maior parte dos membros do corpo administrativo, transferiram-se para o Rio de Janeiro e ali se instalaram por mais de uma década. Com a presença do rei e sua corte em solo brasileiro, foram instituídos, entre outros, a Impressão Régia e a abertura dos portos às nações amigas (1808), a Biblioteca Nacional (1810), o Real Teatro de São João (1813) e a vinda da Missão Artística Francesa (1816). A chegada dos estrangeiros à capital depois de 1808 - os franceses alguns anos mais tarde - também foi um marco importante para se pensar nas novas possibilidades de viver dos cariocas. No que tange o comércio de roupas, por exemplo, a influência dos profissionais europeus foi substancial para as transformações nos modos de vestir das mulheres abastadas que residiam no Rio de Janeiro. A criação desses lugares, e o limiar de um convívio mais próximo com comerciantes, produtos e costumes franceses, ingleses e portugueses, ${ }^{2}$ foram responsáveis, gradualmente, por dar

\footnotetext{
${ }^{2}$ Segundo o historiador Adolfo Morales de los Rios (2000), essas três nacionalidades foram as que vieram em maior número para o Rio de Janeiro. Os ingleses e portugueses atuaram, sobretudo, no ramo de comidas, bebidas, sapatos e os franceses abriram casas de modas e armazéns de fazendas vindas da França.
} 
aspectos mais modernos e europeus à capital brasileira.

Os discursos dos impressos que versavam sobre o cotidiano dos fluminenses também tiveram um peso na propagação desses novos padrões. As histórias escritas por Joaquim Manuel de Macedo e, posteriormente, publicadas em forma de romances cumpriram a tarefa de descrever e prescrever hábitos, comportamentos e posturas consideradas adequadas - e, por vezes, inadequadas - para as leitoras que partilhavam da vida mundana. Segundo a historiadora Mariana Tavares Rodrigues "a leitura da obra macediana nos oferece a seguinte conclusão: existe um Rio de Janeiro antigo em suas páginas" (RODRIGUES, 2010: 21). Assim, tais obras, por serem ficcionais, não deixam de se apresentar como um material interessante para traçarmos uma história da vida social feminina no Oitocentos. Partindo da emergência de uma vida pública, da participação do belo sexo nesses espaços e como, enfim, essas questões foram pinceladas por Macedo, acreditamos que a descrição das roupas e dos adornos das jovens para estarem presentes nessas ocasiões sociais complementam nosso propósito de descrever um tipo de mulher ideal forjada pelos romances e jornais da época. Neste artigo, pois, daremos centralidade para os escritos que foram publicados ainda na primeira metade do século: A moreninha (1844), O moço loiro (1845), Os dois amores (1848) e Rosa (1849).

A partir do estabelecimento de uma imprensa oficial, no ano de 1808, a literatura passou a ter uma importância e uma difusão mais circunscrita em terras brasileiras, pois, romancistas e cronistas também se utilizavam do espaço dos periódicos para publicar contos acerca da vida cotidiana, eram os chamados folhetins. ${ }^{3}$ Essas histórias nacionais ou estrangeiras - eram publicadas nas páginas dos jornais especializados para o público feminino. O intuito era trazer para o espaço do periódico tramas que, depois de algum tempo, poderiam ser compradas em forma de livro. A moreninha, primeiro romance de Macedo, por exemplo, foi publicado em forma de folhetim para depois se tornar livro. A autora Marlyse Meyer, ao apontar algumas características do folhetim, sublinhou que era comum, nessas histórias, paixão, suspense e tragédia. Sendo que "um lencinho não muito longe, o ritmo ágil de escrita que sustentasse uma leitura às vezes ainda soletrante, e a adequada utilização dos macetes diversos que amarrassem o

\footnotetext{
${ }^{3}$ Segundo estudos da pesquisadora Marlyse Meyer, no começo do século XIX, o folhetim designava um lugar preciso do jornal: o roda-pé, geralmente o da primeira página. Tinha uma finalidade precisa: era um espaço vazio destinado ao entretenimento. Tudo que constituiu a matéria e o modo da crônica à brasileira, já era, desde a origem, a vocação primeira desse espaço geográfico do jornal. MEYER, Marlyse (1996). Folhetim: uma história. São Paulo: Companhia das Letras, p. 55.
} 
público e garantissem sua fidelidade ao jornal, ao fascículo e, por fim, o levasse ao livro" (MEYER, 1996: 303) garantiram o sucesso do folhetim. Contos razoavelmente curtos, recheados de suspenses, romances e enredos instigantes, que convidavam o leitor a adquirir o próximo número da folha, foram algumas das características dessas histórias que enfeitavam os periódicos. Assim, a propagação e a fama dessas narrativas indicou também a grande aceitação, pelas leitoras, dos romances, que só começaram a ser publicados no Brasil a partir de 1844 .

O historiador Marcus Carvalho teceu algumas considerações sobre a condição feminina, destacando que "o século XIX também trouxe mudanças para as mulheres da elite [...] A imprensa teve papel fundamental nesse processo, que pouco a pouco, de modo lento, mas contínuo, acarretou uma alteração de costumes" (CARVALHO, 2006: 180). Foi nesse cenário de urbanização, modernização e de um contato mais estreito com os padrões europeus, que as senhoras brasileiras, antes restritas ao lar, começaram a aparecer nos espaços públicos da capital para atividades diversas, como: fazer compras nas lojas, ia à teatros, concertos, bailes, saraus, confeitarias, cafés e a todos os ambientes considerados, por muito tempo, exclusivamente masculinos. $\mathrm{O}$ estudioso sobre o assunto Marco Morel sublinhou que, "em uma sociedade patriarcal como a brasileira, a leitura representou para essas figuras aventuras inéditas de libertação," (MOREL, 2003: 60) isto é, de contato com o mundo exterior. Os primeiros romances nacionais, apesar de estarem restritos a uma parte letrada da população, colocou-se como um "importante difusor de moda e comportamento social nas mocinhas desejosas de consumir e replicar os padrões adotados na Europa," (RODRIGUES, 2010: 20) modelo, por excelência, de civilidade e modernidade para a boa sociedade carioca no Oitocentos.

\section{Retratos da vida mundana feminina}

Dos principais romancistas brasileiros que versaram sobre a vida social fluminense no século XIX, Joaquim Manuel de Macedo, além de ter sido o primeiro, cumpriu um papel importante, pois, os saraus, os bailes, os jantares, as festividades de ordem religiosa, os teatros e todo um rol de ambientes sociais em alta no Oitocentos foram amplamente descritos em suas páginas. Em seu primeiro romance, publicado na década de 1840, não foram raras as menções aos lugares de divertimentos, e, sobretudo, de festividades na cidade. Sobre os saraus as seguintes palavras foram sublinhadas: 
Um sarau é o bocado mais delicioso que temos, de telhado abaixo. Em um sarau todo o mundo tem que fazer. O diplomata ajusta, com um copo de champanha na mão, os mais intrincados negócios; todos murmuram e não há quem deixe de ser murmurado. O velho lembra-se dos minuetes e das cantigas do seu tempo, e o moço goza todos os regalos da sua época; as moças são no sarau como as estrelas no céu; estão no seu elemento; aqui uma, cantando suave cavatina, eleva vaidosa nas asas dos aplausos [...] (MACEDO, 2009: 101).

Além das idades e dos tipos de pessoas que frequentavam os saraus, o romancista ainda destacou o papel protagonista das moças que tocavam o piano. Dessa maneira, as funções femininas começaram a ser minuciosamente demarcadas, por meio dos discursos da época. No que diz respeito às narrativas romanescas, fica evidente que as longas descrições dos comportamentos das personagens anunciavam quais eram os padrões ${ }^{4}$ que deveriam ser seguidos pelas leitoras. Como apontou a citação destacada, tocar piano e cantar eram tarefas próprias das damas, bem como o hábito de dançar junto aos rapazes. A obra macediana, por ter se centrado em personagens facilmente espelháveis pelas leitoras, produziu retratos da sociedade e dos costumes no século XIX. Humberto de Campos ressaltou que "tivesse ele se preocupado em fixar figuras excepcionais, indivíduos singulares no seu meio, pelo caráter, pelos hábitos, pelas paixões, e os seus romances não seriam tão característicos, tão interessantes, tão flagrantemente documentais" (CAMPOS, 2010: 21). A propósito das descrições sobre a vida feminina, Macedo não mediu esforços em narrar aspectos detalhados, como podemos ver nesse trecho de A Moreninha:

A moça da corte escreve e vive comovida sempre por sensações novas e brilhantes, por objetos que se multiplicam e se renovam a todo o momento, por prazeres e distrações que se precipitam; ainda contra a vontade, tudo a obriga a ser volúvel: se chega à janela um instante só, que variedade de sensações! Seus olhos tem de saltar da carruagem para o cavalheiro, da senhora que passa para o menino que brinca, do séquito do casamento para o acompanhamento do enterro! [...] depois, tem o baile com sua atmosfera de lisonjas e mentiras, onde ela se acostuma a fingir o que não sente, a ouvir

\footnotetext{
${ }^{4}$ Aqui estamos nos referindo aos padrões prescritos às mulheres nos espaços de sociabilidade no sentido amplo do termo, como: os modos de vestir, dançar, cumprimentar, tocar o piano, comer, beber e conversar. Todos estes foram, não raras vezes, citados e descritos nos romances de Joaquim Manuel de Macedo.
} 
frases de amor a todas as horas, a mudar de galanteador em cada contradança; depois, tem o teatro, onde cem óculos fitos em seu rosto parecem estar dizendo - és bela! (MACEDO, 2009: 122).

Os locais sociais mencionados pelo escritor revelam que um novo papel foi delegado às senhoras e às moças que participavam da vida mundana acompanhadas de seus pais ou maridos. Além dos espaços de divertimentos apontados pelo excerto, um dos motivos mais comuns para promover bailes ou saraus na capital brasileira oitocentista era os "dias de ano" da gente abastada. Nessas ocasiões, era costume convidar amigos e familiares para tomar chá, dançar, cantar, comer, ou seja, comemorar. Ali, as mocinhas também encantavam os mancebos, por meio do ato de tocar o piano, das valsas e, claro, dos vestidos e penteados novos. A respeito do aniversário da jovem Celina, protagonista de Os dois amores, Macedo narrava que:

Era a noite dos anos da 'Bela órfã'; noite de festa no 'Céu cor-de-rosa', e que deveria ser de inocentes gozos para os numerosos convidados, que enchiam aquela habitação. Além da casa, que estava toda brilhante de luzes, o jardim tão querido de Celina achava-se também iluminados e patentes a aqueles que quisessem aí passear. Não havia, certamente, no 'Céu cor-de- rosa' o luxo deslumbrante das festas dos milionários, que gastam; em compensação, porém, o bom gosto transpirava em tudo (MACEDO, 1949: 97).

Para estudar e mapear a introdução das mulheres cariocas na vida pública é essencial ter em mente esses tipos de eventos que, além de promoverem a socialização, eram raras oportunidades para que as donzelas encontrassem seus pares, conversassem e demonstrassem boas maneiras por meio de suas posturas e vestimentas. As festas de aniversários, os casamentos, as missas de batizados, o Natal e ainda outros tipos de ocasiões comemorativas foram responsáveis por animar e preencher os dias e as noites das famílias abastadas.

A valorização do matrimônio, isto é, o status que passava a adquirir a mulher que se casava, "foi uma tópica essencial na vida das jovens oitocentistas, pois para isso eram criadas" (RODRIGUES, 2010: 96). Uma espécie de confissão feita pela personagem de Os dois amores, Mariana, em conversa com sua sobrinha Celina, revela a importância desse momento e o desespero por não encontrar o pretendente no tempo certo: 
Eu tive medo quando um dia me lembrei de já tinha vinte e quatro anos e estava ainda solteira! [...] Nas sociedades parecia-me ouvir dizer - coitada! quando eu passava perto de um círculo de cavalheiros; eu julgava-se ofendida no meu orgulho, rebaixada na conviç̧ão que eu tinha de ser bela; bela sim, e mais bela que as outras, quando eu vi entrar na sala pelo braço de seus maridos minhas companheiras do colégio, algumas mais moças que eu, e nenhuma tão bonita como eu mesma me supunha! Oh Celina! Eu sentia que o sangue me estava subindo à cabeça naqueles terríveis momentos; concebia desejos de matar-me, e às vezes, fugia para o toilette, e chorava como chora uma criança em desespero! (MACEDO, 1949: 41-42).

A preocupação esboçada pela personagem fazia sentido, justamente, porque uma mulher que não se casasse não era vista com bons olhos pela sociedade e, muitas vezes, "tinha de se conformar à vida cinzenta de solteira, acompanhando a mãe às visitas, entregando-se aos bordados infindáveis ou à educação dos sobrinhos" (SOUZA, 1987: 90). Posto a importância do matrimônio na vida do belo sexo oitocentista, a arte da sedução, os domínios da etiqueta e dos bons modos, fizeram-se extremamente necessários para aquelas que, por esse meio, desejavam conquistar um marido. Ter conhecimento dos "artifícios, para assegurar o futuro ao lado de seus esposos, foi tarefa habitual na vida das mocinhas em idade de se casar" (RODRIGUES, 2010: 96). Joaquim Manuel de Macedo não deixou de dedicar algumas linhas sobre o assunto, sublinhando que a mulher,

apertada no estreito círculo dos deveres domésticos, não terá nunca outras honras, outra glória a desejar, senão aquelas que se devem à fidelidade da esposa, à extremosa maternidade, às virtudes domésticas enfim; e quando uma desgraça cair sobre ela e sobre sua família, ela a quem se não permite outro cuidado, outro culto, que não seja o de sua família, e o de si, isto é, ela que está apertada no estreito círculo dos deveres domésticos, é mais que o homem lamentável. Porque o homem tem o comércio... as armas... a política... muito mais ainda... e enfim a mulher, a mulher tem unicamente o homem (MACEDO, 1980: 305).

Os papéis atribuídos ao belo sexo estiveram, durante um considerável tempo, relacinados ao casamento, ao lar e à família. No entanto, a necessidade de que elas também começassem a cuidar de suas belezas e vestimentas foi ganhando centralidade 
nos escritos da época à medida que a sociabilidade foi ganhando ares mais femininos ao longo do século XIX. Uma jovem de família boa, que soubesse se comportar em sociedade segundo as normas do bom tom e desejasse construir um lar, era o ideal de mulher para aquela sociedade. Estar condizente com os padrões que vinham da Europa também tinha relação com a instrução das moças, no sentido de que, para estarem atualizadas sobre o assunto, tinham de ler os jornais e os romances da época. A importância do bem vestir e adornar cumpriu, portanto, um papel elementar no cotidiano das jovens elegantes, requintadas e seguidoras das novidades que chegavam por meio dos impressos. Assim, o tempo excessivo gasto pelas damas com suas próprias arrumações para sair às ruas, fez com que Macedo escrevesse em um de seus romances:

De ordinário as senhoras fazem voto de sair cedo de casa; pois que, principalmente entre as moças, não se conta uma só, que não beba os ares de uma noite de teatro, de visita às amigas, ou de passeio pela Rua do Ouvidor; mas quando se veem em frente ao toucador (aqui para nós, um toucador é a cachaça das moças) esquecem-se das horas que passam, e de lá se não desgrudam, sem que os pais ou maridos gritem por elas cem vezes, de cansados de esperar que se acham (MACEDO, 1980: 111).

A inserção feminina nos espaços de sociabilidade, como aponta o excerto destacado, foi responsável por um impasse comum às jovens: para se apresentarem bem arranjadas nos eventos era necessário gastar horas com suas arrumações e, ao mesmo tempo, quanto mais cedo chegassem nas festividades mais horas teriam para se divertirem. Macedo, continuando a falar sobre o papel dos senhores que, pacientemente, esperavam as belas saírem de seus trocadores, na citação acima, sublinhava em seguida a fala do pai que estava na sala esperando as mulheres descerem: “Andem, senhoras! Venham meninas! Pois ainda não estão prontas?...” Do trocador responde uma delas: "Já vamos meu paizinho! Estamos pondo os anéis" (MACEDO, 1980: 111). No momento do trocador era necessário que os rapazes tivessem paciência e que as senhoras não perdessem a concentração.

Sobre o despertar de uma preocupação com o bem vestir das mocinhas cariocas, a chegada de um comércio importado da Europa especializado no público feminino contribuiu para o estreitamento da relação entre a mulher e as modas a elas destinadas. Comerciantes e profissionais da beleza, isto é, modistas, cabeleireiros, donos de 
armazéns, sapateiros, chapeleiros e floristas - para citar alguns - começaram a se estabelecer em terras tropicais nos primeiros anos do século XIX, abrindo lojas nas ruas centrais da cidade. A partir de então, as moças fluminenses, além de contarem com serviços e produtos importados, também começaram a ter contato com os jornais e os romances que prescreviam o último gosto. $\mathrm{O}$ ato de vestir, pois, passou de uma necessidade diária para a uma arte engenhosa e repleta de possibilidades. As ocasiões festivas eram motivos para uma jovem abastada encomendar vestido novo com uma modista, comprar sapatos da última moda, estrear um adorno diferente ou pentear-se com um cabeleireiro francês.

O romance Rosa, publicado em 1849, pontuou essa questão por meio de um orçamento apresentado pela protagonista a seu pai, contendo as despesas para o próximo baile da corte. A lista apresentava, entre outros itens, a escumilha branca para o vestido, que custava $24 \$ 000$, o cetim branco para o forro do mesmo, pelo preço de $56 \$ 000$, e o trabalho da modista Madame Gudin, que custaria àquele pai o valor de $70 \$ 000$ (MACEDO, 1910: 10); ou seja, somando ao orçamento as luvas, os sapatos de cetim, o serviço do cabeleireiro e as flores desejadas pela jovem, as despesas com as roupas para um simples baile não sairia por menos de $184 \$ 000 .{ }^{5}$ Nota-se que o feitio do vestido era, de longe, o item mais caro do orçamento e um dos responsáveis pelo valor final exacerbado. Os segundos objetos comprometedores foram os tecidos - cetim e escumilha - usados para fazer o vestido. Outro ponto mencionado, e muito comum entre as donzelas, era a contratação de um cabeleireiro que se dispunha a penteá-la antes da festa. De fato, os produtos e serviços europeus referentes à moda feminina eram oferecidos a preços altíssimos. Joaquim Manuel de Macedo, em O moço loiro, confirmava essa afirmação na fala de um personagem que declarou à sua esposa: "Ignoras que para comprar tetéias francesas, e vestidos de seda para ti e para tua filha, fiquei no fim deste ano empenhado em um conto de réis?” (MACEDO, 1980: 43). As lojas de modas estrangeiras que começaram a tomar as ruas centrais da capital nos primeiros anos do século, de fato, ofertavam seus produtos a preços consideravelmente elevados. As mocinhas e senhoras que desejassem se apresentar no rigor da moda europeia nas festas e outros divertimentos, tinham que solicitar o dinheiro a seus pais ou maridos. Sabendo, pois, os lugares frequentados e até os preços pagos pelas

\footnotetext{
${ }^{5}$ Importante apontar que os preços apresentados por Macedo neste romance eram baseados nos valores reais dos estabelecimentos de moda no Rio de Janeiro. Inclusive, Madame Gudin foi uma modista francesa que, de fato, existiu.
} 
vestimentas, vejamos agora quais eram os tipos de modas mais usadas pelas jovens nesses espaços públicos.

\section{A arte de vestir nas mocinhas de Macedo}

No ano de 1844, o salão de uma grande casa fluminense protagonizou um sarau dançante no Rio de Janeiro. Joaquim Manuel de Macedo, para introduzir a leitora naquela festa, delineava a composição do traje da jovem Carolina com as seguintes palavras:

Entre todas essas elegantes e agradáveis moças, que com aturado empenho se esforçam para ver qual delas vence em graças e encantos, certo que sobrepuja a travessa Moreninha, a princesa daquela festa. Hábil menina é ela! Nunca seu amor próprio produziu com tanto estudo seu trocador e, contudo, dir-se-ia que o gênio da simplicidade a penteara e vestira. Enquanto as outras moças haviam esgotado a paciência de seus cabeleireiros, posto em tributo toda a habilidade das modistas da Rua do Ouvidor e coberto seus colos com as mais ricas e preciosas joias, $\mathrm{d}$. Carolina dividiu seus cabelos em duas tranças, que deixou cair pela costa; não quis adornar o pescoço com seu adereço de brilhantes nem com seu lindo colar de esmeraldas; vestiu um finíssimo, mas simples vestido de garça, que até pecava contra a moda reinante por não ser sobejamente comprido. Vindo assim aparecer na sala, arrebatou todas as vistas e atenções (MACEDO, 2009: 102).

Dando destaque para os aspectos que exaltava a simplicidade de suas vestimentas, fato que não as deixavam menos dignas de encantar os presentes no salão, o romancista atribuiu à Carolina algumas características femininas de beleza e naturalidade. "Pecar contra a moda reinante", por exemplo, foi apontado como uma das graças da jovem. Um ponto importante do excerto é a especificação sobre o estilo do tecido, uma "garça fina e rala", pressupondo que as leitoras dessas narrativas "tinham um conhecimento parcial dos tipos de cortes mais em voga na época" (RODRIGUES, 2010: 78), o que enriquecia e ainda dava um tom a mais de realidade para o enredo. Começando pelos cabelos, descendo para o pescoço, se detendo mais no vestido e finalizando nos pés, o autor permitia que seu público fizesse a imagem completa dos trajes das personagens e também de sua fisionomia. 
$\mathrm{Na}$ ocasião de um outro sarau, em $O$ moço loiro, Macedo igualmente fez um extenso relato da roupa escolhida por Honorina para aquele momento. A moça, nas palavras do autor, estava vestida do seguinte modo:

Dois largos bandos de lindos cabelos negros desciam até dois dedos abaixo das orelhas e para trás se voltavam, indo suas extremidades perder-se por entre longas tranças de perfeitíssimo trabalho, que se enroscavam terminando em cesta; uma grinalda de flores brancas salteadas de pequeninos botões de rosa se entretecia nesse belo tecido de madeixas; duas rosetas de brilhante pendiam de suas orelhas; nenhum enfeite, nenhum adorno ousara cair sobre seu colo, que nu, alvejava, arredondado, virginal e puro; um vestido de finíssimo blonde, que deixava transparecer o branco cetim que cobria o corpinho todo talhado em estreitas pregas, que desenhavam elegantes formas, era debruado por uma longa fila de flores semelhantes a dos cabelos, as quais ainda se deixavam de novo ver formando uma cercadura em que acabavam as mangas curtas, justas e singelas; esse vestido cruelmente comprido para esconder dois pequenos pés calçando sapatinhos de cetim, se terminava por uma simples barra bordada de branco; no braço esquerdo da moça fulgia um bracelete de riquíssimos brilhantes; e, enfim, suas mãos calçavam luvas de pelica branca, guarnecidas de arminho e com borlas de seda frouxa (MACEDO, 1980: 134).

Pode parecer exaustiva a enorme descrição macediana sobre a indumentária da personagem, no entanto, com um olhar mais atento percebe-se que o romancista perpassou por todos os pontos que considerou ser importante destacar sobre uma vestimenta feminina de sarau, ou seja, mais uma vez começou pelos cabelos, passou pelo colo, desceu para o vestido e finalmente chegou aos sapatos. Era, como podemos notar pela quantidade e exuberância dos adereços, um traje completo e no rigor da moda. Façamos algumas considerações breves sobre o excerto acima, comparando-o com a vestimenta da jovem Carolina citada anteriormente. Em uma primeira análise, cabe notar a diferença perceptível nos estilos entre as duas mocinhas. Carolina foi retratada como uma moça simples e elegante ao mesmo tempo. Já Honorina era uma seguidora da moda e sempre se apresentava em sociedade trajando vestuário exclusivo feito pelas mãos talentosas das modistas francesas. Com relação à peça principal escolhida por cada uma das personagens, os dois vestidos estavam condizentes com os 
padrões de vestuário propostos para o momento. Carolina optou pela garça, enquanto Honorina preferiu o cetim. Em termos de valor comercial o segundo era mais caro que o primeiro, pois o cetim, juntamente com a seda, a renda e a escumilha, eram os cortes importados mais valorizados da época. Outro ponto a ser notado são os acessórios e adornos utilizados pelas duas personagens. Enquanto a protagonista de A Moreninha dispensou todos os tipos de adereços que poderiam enfeitar seus cabelos, pescoço ou braços, a vaidosa Honorina fez uso de uma grinalda de flores nos cabelos, colocou em suas orelhas lindos brincos, enfeitou seu braço com um bracelete de brilhante e, para fechar o traje, ainda vestiu luvas de seda. ${ }^{6} \mathrm{O}$ contraste entre os dois trajes apresentados deixa claro que era possível uma moça agradar, tanto se trajando de maneira simples quanto exagerando nos enfeites para atrair os olhares dos convidados. Macedo, assim, aproveitava para imprimir por meio das roupas femininas, seus temperamentos, suas manias, seus sentimentos, isto é, a indumentária podia dizer muito sobre a trajetória de vida e a condição social de uma personagem.

Um aspecto bastante destacado nas narrativas oitocentistas, sobretudo, no que dizia respeito aos trajes das mocinhas, era o uso do branco nos vestidos. Tal cor, segundo os documentos da época, era a mais requisitada pelas jovens em idade de se casar, porque ela representava a pureza e a virgindade. A aparição de uma donzela em uma festividade vestida inteiramene de branco indicava o desejo da moça de contrair matrimônio. Na noite do aniversário da personagem Celina, o escritor carioca delineava a vestimenta da jovem nesses termos:

Celina era como a princesa da festa [...] uma simplicidade feiticeira presidira, como sempre, o seu trocador. Seus longos cabelos estavam atados com graça indizível, mas tão pouco trabalho pedia aquele penteado, que adivinhava-se para logo que era o resultado da destreza de suas mãozinhas; agradava ainda mais por isso. Um pouco para o lado esquerdo de sua cabeça, aparecia um botãozinho de rosa, como surgindo entre as tranças de madeixas. Seu vestido era o único que lhe convinha. Uma virgem pede um vestido branco. A cor branca exprime a alvura de sua alma, a inocência de seu coração. Qualquer outro vestido assenta mal numa virgem (MACEDO, 1949: 97-98).

\footnotetext{
${ }^{6}$ Usar luvas denotava nobreza de berço, educação privilegiada, distanciamento dos trabalhos manuais, tanto para as mulheres como para os homens. No século XIX as luvas posicionaram-se como um acessório sutil, constituindo-se em uma segunda pele de cetim, de seda, de pelica, feita sob medida. Cf. RODRIGUES, Mariana Christina de Faria Tavares (2010). Mancebos e Mocinhas. p. 106-107.
} 
A importância dada ao uso do vestido branco devia-se ao fato de ser a cor mais indicada para exprimir a singeleza e a angelicalidade das mocinhas. À exemplo de Celina, nota-se que o romancista, ao retratar a composição do traje, sublinhou algumas características da própria personagem: graciosa, simples no vestir e singela. Desprovida das vaidades presentes nas outras mulheres, Celina fazia seus próprios penteados para as festas, dispensando os serviços dos cabeleireiros. Tudo quanto fosse do âmbito do natural, do genuíno se encontrava nessa personagem macediana. Cabe, então, pontuarmos algumas semelhanças entre Celina e Carolina - de A moreninha - nos modos de vestir. Isso porque, o final da descrição sobre a vestimenta da primeira se assemelha ao retrato feito da segunda já mencionada em citações anteriores. Sobre a protagonista de Os dois amores, Macedo terminava pontuando que: "Além disto, calçava uns sapatinhos de cetim e mais nada. Para que quer enfeites a formosa donzela? ...para que, se a natureza se incumbe de enfeitá-la com os mais interessantes adornos?" (MACEDO, 1949: 98). Muitas vezes, as citações do romancista exaltava o natural e condenava o artificial. Arrumar-se de forma exagerada para mostrar-se em público, segundo Macedo, denotava certo desvio de caráter da personagem; já aquelas que, dentro dos padrões da moda, sabiam se vestir comedidamente eram as que tinham bons costumes e maiores chances de arrumar casamento.

Para além das ocasiões festivas noturnas, os passeios ao campo e a cavalo durante o dia igualmente fizeram parte do cotidiano feminino oitocentista. O romancista, em um desses passeios matinais, evidenciava a indumentária de Honorina com os seguintes termos:

$\mathrm{O}$ vestido da moça era verde-escuro; nada mais engraçado do que sua cinturinha delicada, do que o corpinho justo de seu vestido, que desenhava as mais encantadoras e voluptuosas formas: ela trazia na cabeça um simples boné preto que, muito pequeno para esconder seus cabelos, deixava cair uma multidão imensa de belos anéis de madeixas negras, que voavam pelos ares na impetuosidade da carreira que trazia o cavalo (MACEDO, 1980: 53).

Após fazer a descrição do belo traje, Macedo sublinhou outras características importantes da mocinha, como o rosto pálido, o rubor das faces, o meigo sorriso, os belos lábios cor de nácar e seus olhos grandes, negros, ardentes, que brilhavam como o 
sol no mais claro dia. Era comum que, nos romances, as descrições dos tipos indumentários viessem acompanhadas dos atributos próprios da natureza feminina no Oitocentos, ou seja, qualidades como a beleza, a meiguice, o romantismo e a delicadeza, eram descritas juntas com as vestimentas, a fim de ajudar as leitoras a visualizarem a personagem por completo e, de fato, ver nelas um modelo de feminilidade.

Sobre os passeios ao campo realizados por essas jovens, discorreremos, em breves palavras, acerca do Passeio Público e da presença das protagonistas de Macedo nesse local em alguns momentos específicos. Celina foi uma das figuras que teve a oportunidade de passear ali ao lado de seu amor e de dois de seus familiares. Nas termos empregados pelo autor, naquela tarde, "uma multidão imensa pejava as alamedas, os dois pequenos largos, e o terraço do Passeio Público da boa cidade do Rio de Janeiro. Era como uma tarde de festa" (MACEDO, 1949: 76). O traje escolhido pela jovem para aquele momento especial foi deste modo descrito:

Vinha ela de vestido de escumilha cor-de-rosa e em corpinho, com os cabelos à napolitana; não trazia nem brincos, nem adereço, nem pulseiras, mas sim lindíssimos braços nus, pois que o vestido era de mangas curtas, e ao mesmo tempo tão comprido, que apenas às vezes se descobria a ponta envernizada de suas pequenas botinas. Uma fita azul, larga de dois dedos, e enlaçada na cintura, era ao demais o seu único ornato (MACEDO, 1949: 167).

No que tange às cores destacadas na indumentária de Celina, temos a combinação do rosa do vestido com a fita azul que envolvia sua cintura. Pelo que podemos perceber por meio das descrições dos trajes mais casuais, isto é, para os passeios à tarde, visitas durante o dia, missas dominicais, entre outros, essas duas cores entravam no leque de possibilidades mais requisitadas para a composição desses tipos de vestuário. Por exemplo, a primeira aparição pública da jovem protagonista de $O s$ dois amores foi assim narrada por Macedo:

Era uma moça de dezesseis anos. Mercê da hora e do lugar, vinha ela em livre desalinho. Vestia um vestido azul-claro, leve, de mangas curtas, e comprido, como é moda ainda hoje. Cabelos castanhos, quase pretos, caíam bastos, longos e ondeados até um palmo do chão, de modo a fazer inveja a essas gregas, de quem fala Gemelli; sua fronte era branca e lisa; seus olhos 
azuis e belos, como os das mais belas mulheres do Norte. Fugitivo rubor lhe assomava às faces. Formavam sua boca breve e ornada de lindíssimos dentes, dois lábios úmidos e rubros, como o bico de uma trocaz. Seu nariz era em feito como os das beldades da Circássia; e a seu colo altivo e branco como a neve, seguia um seio alvo palpitante... perigoso de se comtemplar (MACEDO, 1949: 12).

As roupas escolhidas por Celina, na maioria das vezes, exprimiam a simplicidade, a timidez e o recato da própria personagem. A ausência de adornos era outro traço marcante da indumentária da jovem. Em raras ocasiões, via-se em seu pescoço um colar, ou um bracelete adornando seus braços. A preferência da personagem pelas cores mais claras - rosa, azul e branco - indicavam a singeleza e a pureza de seu coração. Tons escuros e adornos em exagero não convinham para uma menina de dezesseis anos que procurava um casamento, como era o caso de Celina.

Uma das personagens mais marcantes de Macedo, a jovem Rosa, também em idade de se casar, era, entre todas as outras citadas, a mais adepta aos luxos da moda. Em todas as ocasiões festivas da corte, ela fazia muita questão de se mostrar em trajes exclusivos, isso porque tinha por preceito não repetir nenhuma roupa ou adorno em dois momentos diferentes, como demonstrava a personagem nesta fala:

Meu tio não compreende o que é essa guerra feminina que se chama baile! Oh! Mas é uma luta constante, terrível, enraivada, que não se acaba nunca enfim! A mulher hostiliza a mulher de todas as maneiras: se pode, morde-lhe o coração, espinha-lhe a vida [...] e se não pode, ao menos desgrenha-lhe os cabelos e rasga-lhe o vestido! Em uma palavra, os vestidos, os enfeites, os brincos, os adereços, as flores com que eu fui a um baile há seis meses passados, estão ainda na memória de todas as minhas competidoras: apareça eu amanhã como me mostrei há seis meses passados, e cada uma delas irá dizer baixinho à outra: - É o mesmo vestido! São as mesmas flores! É tudo o mesmo! (MACEDO, 1910: 26).

O desabafo da protagonista, que chama as outras mulheres de "competidoras", revelava o desejo feminino de sempre se mostrar em sociedade trajando vestes novas e exclusivas, tanto para impressionar os rapazes quanto para despertar inveja nas outras moças. As senhoras que frequentavam os bailes faziam questão de reparar-se umas às 
outras e criticar os modelos escolhidas por suas adversárias. Um diálogo entre duas damas da alta sociedade carioca ilustrava justamente este ponto: “- D. Joaninha, você reparou no vestido de chalim de D. Carlota? Quanto a mim, está absolutamente fora de moda. Ainda que estivesse na moda, não há nada que nela se assente bem. - Ora, é um pau vestido! Tem uma testa maior que a rampa do largo do Paço!” (MACEDO, 2009: 80). Críticas análogas a esta eram bem comuns nas páginas de Macedo, demonstrando que as relações femininas, quase sempre, perpassavam pela beleza e pela roupa. Não por acaso, os assuntos mais comentados nas conversas e reuniões de mulheres eram os últimos eventos, as roupas com que foram vestidas outras senhoras, as novidades chegadas de Paris e ainda outras informações sobre moda e beleza.

Por fim, ao longo de toda essa exposição, chegamos à conclusão que é possível escrever uma história dos modos de vestir e da vida social feminina no século XIX por meio dos primeiros romances de Joaquim Manuel de Macedo. Percebemos que, além das páginas macedianas trazerem à tona tipos de mulheres exemplares, as descrições de modas, os preços, o cotidiano, os eventos sociais e a fisionomia de suas personagens foram muito fiéis à realidade partilhada pela boa sociedade carioca daquele tempo. Por isso, nos trabalhos sobre a moda, a beleza e a vida social das mulheres oitocentistas no Rio de Janeiro, o romancista continua sendo referência primordial para a investigação dos historiadores, pois, através do estudo da sociedade carioca, conseguiu aproximar ficção e realidade.

\section{Fontes}

MACEDO, Joaquim Manuel de (2009 [1844]. A moreninha. São Paulo: Ciranda Cultural. (1980 [1845]). O moço loiro. Rio de Janeiro: Edições de Ouro. (1949 [1848]). Os dois amores. São Paulo: Editora Melhoramentos. (1910 [1849]). Rosa. Rio de Janeiro: H. Garnier. (vol. I e II).

\section{Referências biliográficas}

ALENCASTRO, Luiz Felipe de (1997). História da vida privada no Brasil. São Paulo: Vol. 2, Companhia das Letras.

AMANTINO, Márcia e PRIORE, Mary Del (Org) (2011). História do corpo no Brasil. São Paulo: Editora UNESP.

BONADIO, Maria Claudia; MATTOS, Maria da Fátima da S. Costa de (Orgs) (2011). História e cultura de moda. São Paulo: Estação das Letras e Cores. 
BOTELHO, Ângela Vianna; REIS, Liana Maria (2008). Dicionário Histórico Brasil: colônia e império. Ed. 6. Belo Horizonte: Autêntica.

BOUCHER, François (2012). História do vestuário no Ocidente: das origens aos nossos dias. São Paulo: Cosac Naify.

BUITONI, Dulcília Schroeder (2009). Mulher de papel: a representação da mulher pela imprensa feminina brasileira. São Paulo: Summus.

CAMPOS, Humberto de (2010). As modas e os modos nos romances de Macedo. In: Antologia da Revista da Academia Brasileira de Letras. Rio de Janeiro: Academia Brasileira de Letras.

CARVALHO, Marcus J. M. de (2006). A imprensa na formação do mercado de trabalho feminino no século XIX. In: NEVES, Lúcia Maria Bastos P. \& FERREIRA, Tania Maria Bessone da C. (Orgs.) História e Imprensa. Rio de Janeiro: DP\&A FAPERJ.

COSTA, Nelson (1961). Páginas cariocas: trechos de autores brasileiros sobre a Cidade do Rio de Janeiro. Rio de Janeiro: Coleção Cidade do Rio de Janeiro.

FORSTERS, Edward (1998). Aspectos do romance. 2 ed. São Paulo: Globo.

FRANÇA, Jean Marcel Carvalho (1999). Literatura e Sociedade no Rio de Janeiro oitocentista. Lisboa: Imprensa Nacional/Casa da Moeda.

FREYRE, Gilberto (1997). Modos de homem e modas de mulher. Rio de Janeiro: $3^{\text {a }}$ edição, Record.

HALLEWELL, Laurence (2005). O livro no Brasil: sua história. São Paulo: Editora da Universidade de São Paulo.

ITALIANO, Isabel; VIANA, Fausto; BASTOS, Desirée; ARAÚJO, Luciano (Orgs) (2015).Para vestir a cena contemporânea: moldes e moda no Brasil do século XIX. São Paulo: Estação das Letras e Cores.

LIMA, Oliveira (1996). D. João VI no Brasil. Rio de Janeiro: 3 ed. Cidade: Topbooks.

LIPOVETSKY, Gilles (1989). O império do efêmero: a moda e seu destino nas sociedades modernas. São Paulo: Companhia das Letras.

LOBO, Eulália Maria Lahmeyer (1978). História do Rio de Janeiro. Rio de Janeiro: IBMEC.

MACEDO, Joaquim Manuel de (2005). Um passeio pela cidade do Rio de Janeiro. Brasília: Edições do Senado Federal.

MACHADO, Ubiratan (2001). A vida literária no Brasil durante o Romantismo. Rio de Janeiro: Editora UERJ.

MEYER, Marlyse (1996). Folhetim: uma história. São Paulo: Companhia das Letras.

MOREL, Marco. (2003). Palavra, imagem e poder: o surgimento da imprensa no Brasil do século XIX. São Paulo: DP\&A.

MOISÉS, Leyla Perrone (Org.) (2013). Cinco séculos de presença francesa no Brasil. São Paulo: EDUSP.

NEEDELL, Jeffrey D (1993). Belle Époque Tropical: sociedade e cultura de elite no Rio de Janeiro na virada do século. São Paulo: Companhia das Letras.

RAINHO, Maria do Carmo Teixeira (2002). A cidade e a moda: novas pretensões, novas distinções. Universidade de Brasília: Brasília.

RODRIGUES, Mariana Christina de Faria Tavares (2010). Mancebos e mocinhas: moda na literatura brasileira do século XIX. São Paulo: Estação das Letras e Cores.

SOUZA, Gilda de Mello e (1987). O espírito das roupas: a moda no século XIX. São Paulo: Companhia das Letras. 
Artigo recebido em 18 de janeiro de 2019.

Aprovado em 19 de maio de 2019.

DOI: 10.12957/intellectus.2019.40625 